\title{
Investigating synchronous and asynchronous class attendance as predictors of academic success in online education
}

\author{
Johanna Elizabeth Nieuwoudt \\ Southern Cross University, Australia
}

Learning is facilitated by participation and interaction and can be synchronously or asynchronously in online education. This study investigated the relationship between students' academic success and online interaction and participation and explored their class attendance (synchronous virtual classes and/or watching the recorded virtual classes) in the online study mode of an enabling program at Southern Cross University in Australia. The Preparing for Success at SCU Program equips students with study skills for success at university. The data were retrieved from usage information data provided by the Blackboard Learn learning management system. The results show that it is important for students to attend class, but it does not necessarily make a difference whether students attend synchronous virtual classes or watch the recordings of the virtual classes. A significant relationship was found between academic success and the number of hours students participated in and interacted with the online learning system. Academic success may be increased by providing various options for students to participate and interact online, and to attend classes synchronously or asynchronously. The flexibility of online education can enable students to be successful in their studies. The inclusion of varied activities is therefore recommended to increase academic success in online education.

\section{Implications for practice or policy:}

- Online students' academic success may be increased by providing various options for students to participate and interact online, and to attend virtual classes synchronously and/or asynchronously.

- Course designers and educators should include varied activities to provide online students with multiple opportunities to interact and participate synchronously and/or asynchronously.

- University educators should record synchronous virtual classes and make the recorded virtual classes available to students.

Key words: academic success, enabling, online learning, synchronous learning, asynchronous learning, quantitative research

\section{Introduction}

Many university educators promote class attendance, as it is a commonly held belief that academic success is related to class attendance. Specifically, students who attend classes on a regular basis achieve higher grades than students who do not attend classes on a regular basis. However, class attendance simply means that the student is physically present (Credé, Roch, \& Kieszczynka, 2010). Oral participation is presumed to be linked to learning (Bainbridge Frymier \& Houser, 2016), thus many university educators encourage students to speak in class. It is assumed that quiet students are less engaged in learning (Bainbridge Frymier \& Houser, 2016). However, quiet students may be engaged in learning despite not being verbal in class, as the quiet students may be taking notes and/or listening (Abdullah, Rahamah Abu Bakar, \& Mahbob, 2012). Meyer $(2007 ; 2008)$ posited that quiet, but engaged, students may be expressing their engagement in the form of nonverbal attentive behaviours such as head nods, eye contact, responsive facial expressions, and open and alert body language. It is therefore recommended that university educators monitor the students' nonverbal behaviours instead of only relying on verbal behaviours (Bainbridge Frymier \& Houser, 2016). However, this is not possible in online education, as students are not attending a physical class.

Online education makes it possible for students to access higher education without physically attending classes (Butner, Smith, \& Murray, 1999). This is especially important for regional areas, where students may not have otherwise had access to higher education (National Centre for Student Equity in Higher 
Education, 2017). Online education continues to increase in popularity (Kahu, Stephens, Leach, \& Zepke, 2013) with most colleges and universities offering degree programs and courses online. It appears that online education increases higher education access for students who are mature-age, first-in-family (Open Universities Australia, 2015), from regional and remote areas, from low socio-economic status backgrounds, Aboriginal and Torres Strait Islander (Indigenous) students, and students with disability (Stone, 2017). Online education can permit students with limited financial resources to study at university, as there are no travel and relocation costs (Dai, 2019). While online education does increase access to higher education, the attrition rates are higher for online students compared to on-campus students (National Centre for Student Equity in Higher Education, 2017; Stone, 2017). To decrease attrition rates and increase academic success in online education, it is important to understand the various ways students interact and participate in the online environment.

Interaction in online learning, the equivalent of face-to-face discussions in physical classes, occurs in asynchronous discussion forums, via email, and in synchronous chatrooms (Delahunty, Jones, \& Verenika, 2014). New technologies provide flexibility in online education (Aoki, 2012). For example, students can use their mobile devices to access and participate in the online environment (Gikas \& Grant, 2013). It is also possible to simulate face-to-face classes in online education (Skylar, 2009). Students can attend synchronous virtual classes from any location using any internet connected device. Synchronous virtual classes can be very interactive with the use of web conferencing products such as Blackboard Collaborate тм available in the Blackboard Learn learning management system (LMS). The students and the teacher can interact online during live synchronous sessions. Presentation slides can be uploaded and the students and the teacher can communicate orally or exchange messages through typing in the chat box, use emoticons, and write on the shared whiteboard. The students can interact with the teacher, fellow students, and the content in real time when attending a virtual class (McBrien, Jones, \& Cheng, 2009). Virtual classes can also be recorded and made available to students to watch at a convenient time if they are unable to attend the synchronous class, further increasing the flexibility of online education. It is the convenience (McBrien et al., 2009) and flexibility that makes online learning attractive to students (Schoech, 2000). Self-directed learning enables the online student to decide how and when to interact and participate.

Self-directed learning is important in online education (Sumuer, 2018), as students engage in learning individually and also interact with fellow students and the teacher (Brookfield, 2009; Garrison, 1997). Learning is facilitated when students participate (Wenger, 1998) and interact with the content, the teacher, and fellow students (Anderson \& Garrison, 1998). Online learner participation can be defined as "a complex process comprising doing, communicating, thinking, feeling and belonging, which occurs both online and offline" (Hrastinski, 2008b, p. 1761). Online learner participation varies from merely accessing the online learning system to taking part in rewarding discussions (Hrastinski, 2008b). Participation can be increased in an online environment as students have more time to process information and compile a response (Hrastinski, 2008a). It appears that students, especially shy students, may feel more comfortable expressing their thoughts and/or ask questions in an online environment compared to traditional face-to-face classes (Caspi, Chajut, Saporta, \& Beyth-Maron, 2006; McBrien et al., 2009). Conversely, online learner participation may be negatively affected by technology malfunctions (McBrien et al., 2009) and by the permanency of written communication (Caspi et al., 2006) in discussion forums, emails, and chatrooms. The online learning environment should be flexible to provide choice and control, and opportunities for students to collaborate (Sumuer, 2018).

In order to facilitate learning and improve academic success in online education, it is important to understand the different ways students access and participate in the online learning system. The flexibility of online learning provided by new technologies means students can interact on the LMS in a multitude of ways, including choosing to attend synchronous virtual classes and/or watch recordings of the synchronous virtual classes. Previous research indicated that interactive synchronous virtual classes are effective to facilitate learning, and that students would rather learn via highly interactive synchronous virtual classes than asynchronously (Offir, Lev, \& Bezalel, 2008; Skylar, 2009). However, it is not known if academic success is negatively affected if students watch recorded virtual classes instead of attending synchronous virtual classes. The purpose of this research is to investigate the role class attendance may play in students' academic success in two online subjects from a regional university in Australia. This research aimed to: (a) investigate the relationship between students' academic success and online interaction and participation, (b) determine if there is a difference in academic success across different class attendance patterns, and (c) 
determine if academic success can be predicted by attendance of synchronous virtual classes and/or recorded classes.

\section{Material and methods}

This study was conducted to examine the academic success, online interaction, and online learner participation of 164 students enrolled in two subjects as part of the Preparing for Success at SCU Program at Southern Cross University (Managing Your Study =117; Studying Science =47). All students were enrolled in the online study mode of the program in Session 2, 2018.

\section{Context}

The Preparing for Success at SCU Program is an enabling program (i.e., a pre-award program that prepares students for the rigours of higher education) at Southern Cross University. The Preparing for Success at SCU Program is 12 weeks in duration and consists of four subjects. Southern Cross University is a regional university in northern New South Wales, Australia. The program is offered in all three sessions of the year and can be studied online or on campus at Coffs Harbour, the Gold Coast, and Lismore. Three compulsory subjects equip students with communication, study, and numeracy skills. The fourth subject is an elective, and students can choose between an arts-based or science-based subject. Successful completion of the program provides a distinct pathway into tertiary study at Southern Cross University.

This research study focused on the Managing Your Study subject (one of the compulsory subjects) and the Studying Science subject (an elective subject), as the researcher is a teacher in the two subjects. The subject Managing Your Study promotes independent learning by building an understanding of the culture of learning at university and creating a toolkit of learning strategies and skills. The subject Studying Science introduces students to science, and key concepts in biology, physics, and chemistry. For online students enrolled in the Managing Your Study and Studying Science subjects, weekly classes were held in Blackboard Collaborate TM (via the Blackboard Learn LMS), a virtual classroom where students and the teacher interacted online during live synchronous sessions. There was one synchronous virtual class per week for each subject. Presentation slides were uploaded and the students and the teacher communicated orally and exchanged messages through typing in the chat box, using emoticons, and writing on the shared whiteboard. Classes consisted of explanations of content, activities to test understanding (e.g., drag and drop activities, labelling activities, answering questions in the chat box, writing key words on the shared whiteboard). Attendance of the synchronous virtual classes were not mandatory. The virtual classes were recorded and made available to students to watch at a convenient time if they were unable to attend the live synchronous virtual class. The presentation slides and additional learning resources were available for students in the LMS. Managing Your Study students had access to the Study Guide in a portable document format (PDF). Studying Science students had access to the interactive online Study Guide, consisting of reading content, video clips, and interactive activities that are compatible with mobile devices. Students had to logon to the LMS to access the interactive Study Guide. The Study Guide supplements the weekly classes. Weekly activities related to the class content were posted on the discussion forum. Students were encouraged to participate on the discussion forum, but it was not mandatory nor graded. Students were also encouraged to ask questions related to the assessments on the discussion forum.

\section{Data collection}

The data were retrieved by the researcher from usage information data provided by the LMS. The usage information data were retrieved for all students enrolled in the Studying Science subject and in the Managing Your Study subject. The retrieved data for each subject consisted of: number of hours on the LMS, the number of times the synchronous virtual classes were attended, the number of times the recorded classes were watched, the number of views of the discussion board, the number of posts made on the discussion board, and the number of times the Study Guide was viewed. Final grades (in percentage format) were acquired from the LMS as an indicator for academic success. Ethics approval was obtained from the Human Research Ethics Committee of Southern Cross University (approval number ECN-16-039). 


\section{Data analysis}

Descriptive statistics and inferential statistical tests were used to explore the study population's characteristics. Mean $(M)$ values of the measurements with standard deviation $(S D)$ were reported. Variables were not normally distributed (Kolmogorov-Smirnov statistical significance value $=.000$ ), thus non-parametric tests were used. The level of significance was set at $p \leq .05$. Spearman rank order correlation $\left(r_{s}\right)$ analyses were undertaken to examine the associations between final grade and student interaction on the LMS. Kruskal-Wallis tests were undertaken to assess differences in the patterns of class attendance, and to examine differences between enrolment modes in terms of final grades and class attendance. Four different patterns of class attendance were recognised, based on Chapin (2018):

Group 1: attended 50\% or more synchronous virtual classes and accessed less than $50 \%$ recorded classes,

Group 2: attended less than 50\% synchronous virtual classes and accessed 50\% or more recorded classes,

Group 3: attended synchronous virtual classes and accessed recorded classes $50 \%$ or more, and

Group 4: attended synchronous virtual classes and accessed recorded classes less than $50 \%$.

Bonferroni corrections were made to control for possible type 1 error for contrast analyses. Mann-Whitney $U$ tests were undertaken to determine the statistically significant differences between groups. Effect size was calculated by $z$ /square root of $n$. Standard multiple regression analysis was conducted to determine how much variance in final grade can be explained by attendance of synchronous virtual classes or recorded classes, and to determine which the best predictor of final grade is. Statistical analyses were performed using IBM SPSS, Statistics 24 (IBM SPSS; Chicago, Illinois).

\section{Results}

The mean final score achieved was 52.83 (i.e., a Pass grade) out of a possible $100(S D=28.13)$ for the Managing Your Study subject. The mean final score achieved in the Studying Science subject was 58.02 (i.e., a Pass grade) out of a possible $100(S D=21.55)$. Grades ranged from Fail to High Distinction (Table 1). Fail grades were awarded to students as a result of non-submission of one or more assessments, or an overall score of less than $50 \%$ for the subject.

Table 1

Students' final grade distribution

\begin{tabular}{|c|c|c|c|c|}
\hline \multirow[t]{2}{*}{ Final grade } & \multicolumn{2}{|c|}{ Managing Your Study } & \multicolumn{2}{|c|}{ Studying Science } \\
\hline & $n$ & $\%$ & $n$ & $\%$ \\
\hline Fail (0 -49\%) & 42 & 35.90 & 10 & 21.28 \\
\hline Pass $(50-64 \%)$ & 20 & 17.09 & 13 & 27.66 \\
\hline Credit $(65-74 \%)$ & 27 & 23.08 & 14 & 29.79 \\
\hline Distinction $(75-84 \%)$ & 22 & 18.80 & 9 & 19.15 \\
\hline High Distinction $(85-100 \%)$ & 6 & 5.13 & 1 & 2.13 \\
\hline
\end{tabular}

Student online interaction and online participation are shown in Table 2. Students had higher (mean) levels of online interaction and participation in the Managing Your Study subject in four of the six measured areas, compared to the Studying Science subject. 
Table 2

Students' online interaction and online participation on the learning management system

\begin{tabular}{|c|c|c|c|c|c|c|c|c|}
\hline & \multicolumn{4}{|c|}{ Managing Your Study } & \multicolumn{3}{|c|}{ Studying Science } & \multirow[b]{2}{*}{ Range } \\
\hline & $\begin{array}{l}\text { Students } \\
\quad(n)\end{array}$ & $M$ & $S D$ & Range & $\begin{array}{l}\text { Students } \\
\quad(n)\end{array}$ & $M$ & $S D$ & \\
\hline $\begin{array}{l}\text { Hours on Learning } \\
\text { Management System }\end{array}$ & 117 & 32.41 & 32.92 & $\begin{array}{c}0.17- \\
25526\end{array}$ & 47 & 25.12 & 21.43 & $\begin{array}{c}0.72- \\
13924\end{array}$ \\
\hline $\begin{array}{l}\text { Synchronous virtual class } \\
\text { attendance }\end{array}$ & 117 & 3.74 & 4.25 & $0-12$ & 47 & 1.87 & 3.00 & $0-11$ \\
\hline Watching recorded classes & 117 & 3.89 & 4.52 & $0-22$ & 47 & 5.09 & 5.87 & $0-28$ \\
\hline Discussion Board views & 117 & 29.79 & 40.38 & $0-268$ & 47 & 13.00 & 23.17 & $0-128$ \\
\hline Posted on Discussion Board & 117 & 4.60 & 5.99 & $0-25$ & 47 & 1.81 & 4.55 & $0-25$ \\
\hline Study Guide views & 117 & 5.50 & 5.12 & $0-25$ & 47 & 10.68 & 10.71 & $0-56$ \\
\hline
\end{tabular}

Spearman rank order correlation analyses found significant correlations between final grades and student activity on the LMS, except between final grade in the Studying Science subject and Study Guide views, as presented in Table 3 .

Table 3

Spearman rank order correlation between final grades and students' online interaction and participation on the learning management system

\begin{tabular}{|c|c|c|c|c|c|c|c|}
\hline & & $\begin{array}{l}\text { Hours on } \\
\text { Learning } \\
\text { Management } \\
\text { System }\end{array}$ & $\begin{array}{l}\text { Synchronous } \\
\text { virtual class } \\
\text { attendance }\end{array}$ & $\begin{array}{l}\text { Watching } \\
\text { recorded } \\
\text { classes }\end{array}$ & $\begin{array}{l}\text { Discussion } \\
\text { Board } \\
\text { views }\end{array}$ & $\begin{array}{l}\text { Posted on } \\
\text { Discussion } \\
\text { Board }\end{array}$ & $\begin{array}{l}\text { Study } \\
\text { Guide } \\
\text { views }\end{array}$ \\
\hline \multirow[t]{3}{*}{$\begin{array}{l}\text { Managing } \\
\text { Your Study }\end{array}$} & $\begin{array}{l}\text { Final } \\
\text { grade }\end{array}$ & $.774\left(r_{s}\right)$ & $.596\left(r_{s}\right)$ & $.730\left(r_{s}\right)$ & $.727\left(r_{s}\right)$ & $.544\left(r_{s}\right)$ & $.508\left(r_{s}\right)$ \\
\hline & & $<.001(p)$ & $<.001(p)$ & $<.001(p)$ & $<.001(p)$ & $<.001(p)$ & $<.001(p)$ \\
\hline & & $114(n)$ & $114(n)$ & $114(n)$ & $114(n)$ & $114(n)$ & $114(n)$ \\
\hline \multirow[t]{3}{*}{$\begin{array}{l}\text { Studying } \\
\text { Science }\end{array}$} & $\begin{array}{l}\text { Final } \\
\text { grade }\end{array}$ & $.522\left(r_{s}\right)$ & $.416\left(r_{s}\right)$ & $.420\left(r_{s}\right)$ & $.527\left(r_{s}\right)$ & $.369\left(r_{s}\right)$ & $.273\left(r_{s}\right)$ \\
\hline & & $<.001(p)$ & $.004(p)$ & $.004(p)$ & $<.001(p)$ & $.013(p)$ & $.069(p)$ \\
\hline & & $45(n)$ & $45(n)$ & $45(n)$ & $45(n)$ & $45(n)$ & $45(n)$ \\
\hline
\end{tabular}

In the Studying Science subject, a Kruskal-Wallis test revealed no statistically significant difference in final grade across four different class attendance patterns (Group 1, $n=2$; Group 2, $n=12$; Group 3, $n=5$; Group 4, $n=26), \chi^{2}(3, n=114) 8.391, p=.039$; with a revised alpha level of 0.008 . In the Managing Your Study subject, a Kruskal-Wallis test revealed a statistically significant difference in final grade across four different class attendance patterns (Group 1, $n=11$; Group 2, $n=9$; Group 3, $n=30$; Group 4, $n=64$ ), $\chi^{2}$ $(3, n=114) 49.92, p=<.001$; with a revised alpha level of 0.008 . Mann-Whitney $U$ tests found significant differences in the final grade between Group $1(M d=73.00, n=11)$ and Group $4(M d=44.25, n=64), U$ $=124.500, p=.001, r=-0.394$; between Group $2(M d=66.00, n=9)$ and Group $3(M d=75.25, n=30)$, $U=67.000, p=.023, r=-0.363$; between Group $2(M d=66.00, n=9)$ and Group $4(M d=44.25, n=64)$, $U=119.000, p=.005, r=-0.332$; and between Group $3(M d=75.25, n=30)$ and Group $4(M d=44.25, n$ $=64), U=157.500, p=<.001, r=-0.672$.

Standard multiple regression analyses were used to assess if synchronous virtual class attendance and attendance of recorded classes predicted students' final grades; and to determine which the best predictor of final grade is. The results of the regression indicated the two predictors explained $40.6 \%$ of the variance in the Managing Your Study subject (Adjusted $R^{2}=.406, F(2,111)=39.558, p=<.001$ ). It was found that the attendance of recorded classes $(\beta=.418, p=<.001)$ makes the largest unique contribution, although 
attendance of synchronous virtual classes also made a statistically significant contribution $(\beta=.282, p=$ $.006)$ to predict final grades. However, in the Studying Science subject, the results of the regression indicated the two predictors explained only $16.1 \%$ of the variance (Adjusted $R^{2}=.161, F(2,42)=5.209, p$ $=.010)$. It was found that the attendance of synchronous virtual classes did not significantly predicted final grade $(\beta=.235, p=.127)$, nor did the attendance of recorded classes significantly predicted final grade $(\beta$ $=.295, p=.058)$.

In summary, Kruskal-Wallis tests revealed a statistically significant difference in final grade across four different class attendance patterns in the Managing Your Study subject, but no statistically significant difference was revealed in the Studying Science subject. Standard multiple regression analyses indicated that the attendance of synchronous virtual classes and recorded classes predicted students' final grades in the Managing Your Study subject, but not in the Studying Science subject.

\section{Discussion}

It is generally accepted that learning is facilitated when students interact with the content, the teacher, and fellow students (Anderson \& Garrison, 1998). In this study, students spent on average 32.41 hours on the LMS in the Managing Your Study subject and 25.12 hours in the Studying Science subject (Table 2) interacting with the content, the teacher, and fellow students. There was a significant relationship between the final grades and the number of hours students were on the LMS (Table 3). This is in agreement with other researchers who also found that students who spent more time online had higher grades compared to students who spent less time online (e.g., Davies \& Graff, 2005; Nieuwoudt, 2018; Wong, 2013). However, Perera and Richardson (2010) found no relationship between the final grades and the number of hours students spent online. Students in the Studying Science subject had a higher mean final score (58.02) compared to students in the Managing Your Study subject $(M=52.83)$, despite spending less time on the LMS. The level of interactivity can be quantitatively determined by counting the number of times a student actively engages with the content, the teacher, or fellow students (Anderson, 2003). It can therefore also be quantified by determining the time students spend on the LMS. However, the quality of the interactions may be more important than the quantity of interactions (Bernard et al., 2009).

The quality of interactions can be increased by including high-quality learning activities (Bernard et al., 2009). One option is utilising web conferencing products such as Blackboard Collaborate TM to facilitate interactive synchronous virtual classes. However, the provision of synchronous virtual classes is in opposition to the idea that online students can access their learning 'anytime, anywhere' (Skylar, 2009) as the virtual class is at a set time and students do need internet access. To increase flexibility, the synchronous virtual classes were recorded in the current study and made available to students to watch at a convenient time if they are unable to attend the synchronous class. The current study found a significant relationship between attending synchronous virtual classes and the final grades, and also between watching recorded classes and the final grades (Table 3). Previous research found that interactive synchronous virtual classes are effective to facilitate learning, and that students would rather learn via highly interactive synchronous than asynchronous virtual classes (Offir et al., 2008; Skylar, 2009). However, in this study no difference was found in the final grades of students who attended synchronous virtual classes and students who watched the recorded virtual classes. In the Managing Your Study subject, both the attendance of synchronous virtual classes and the watching of recorded virtual classes significantly predicted final grades, with the watching of recorded classes making the largest unique contribution. In contrast, in the Studying Science subject, attending synchronous virtual classes did not significantly predict final grades. Nor did watching recorded classes. This is in agreement with the results of the meta-analysis of Allen et al. (2004) which indicated that the use of synchronous interactive technology does not necessarily mean increased final grades. This is also similar to previous research that found no difference in final grades when comparing different patterns of attending face-to-face lectures and accessing recordings of the lectures (Chapin, 2018; Kinash, Knight, \& McLean, 2015). This may be due to vicarious interaction when students learn from watching other students interact (Sutton, 2001).

Some students find the high level of interactivity overwhelming, as it can be over-stimulating (McBrien et al., 2009). According to cognitive load theory (Chandler \& Sweller, 1991), cognitive load may be increased by multitasking consisting of listening to the teacher, viewing the presentation slides, processing new information, typing a response in the chat box, and reading comments in the chat box during a synchronous virtual class. The increased cognitive load may inhibit learning (Sweller, 1988). When watching the 
recording of the classes, students have more control (Li \& Irby, 2008), as students can pause and rewind the recording, thus increasing time to process the information and consequently decreasing the cognitive load. However, students are unable to interact with the teacher in the recorded class.

Students can learn vicariously by watching other students interact (Bandura, 1986), as a form of active learning (Hrastinski, 2009). This may be in recorded classes or in the discussion board. In this study significant relationships were found between students' final grade and posting on the discussion board, as well as between students' final grade and accessing the discussion board (Table 3). This finding supports other researchers (Cheng, Pare, Collimore, \& Joordens, 2011; Davies \& Graff, 2005; Romero et al., 2013) who found that participation in online discussion forums are related to students' final grade. However, participation is too complex to be judged on only the quantity of discussion board posts (Kebritchi et al., 2017). The quality of interaction is important and is difficult to determine, especially as it may be different for different students (Anderson, 2003). Hrastinski (2009, p. 81) ascertain that participation "is not synonymous with talking or writing". Some students may not be actively participating in the discussion forum but may be cognitively present (Garrison \& Cleveland-Innes, 2005) and learning vicariously by reading discussion board posts (Nieuwoudt, 2018). In this study, students rarely posted any messages on the discussion board, although they did view the discussion board multiple times (Table 2). This pattern of interaction is often seen when participation in the discussion board is not mandatory (Cheng et al., 2011), as was the case in this study. A small number of students typically participate often on the discussion board despite not being mandatory, while the majority of students do not post any messages (Cheng et al., 2011). Online learner participation varies from merely accessing the online learning system to taking part in rewarding discussions (Hrastinski, 2008b).

As stated previously, by including high-quality learning activities the quality of interactions can be increased (Bernard et al., 2009). Students should be provided with multiple and varied activities (Hattie, 2012), and opportunities should be provided to engage with information in various ways (Biggs \& Tang, 2007). The interface for content delivery is deemed to be increasingly important, as many students are using mobile devices for studying (Stone, 2017). An interactive Study Guide compatible with mobile devices was available in the Studying Science subject, but not in the Managing Your Study subject. A significant relationship was found between students' final grades and the number of times students viewed the PDF Study Guide in the Managing Your Study subject, but not between the interactive Study Guide and students' final grades in the Studying Science subject. Students in the Studying Science subject did, on average, access the interactive Study Guide more $(M=10.68)$ compared to viewing the PDF Study Guide $(M=5.5)$ in the Managing Your Study subject (Table 2). It is possible that some students downloaded and saved the PDF on their personal devices, resulting in the LMS not being able to capture the usage data related to the PDF Study Guide. Online students have more control over their learning and learning materials, but to be successful in their learning the students have to be self-motivated and self-directed (Kebritchi et al., 2017). Self-directed learning can be facilitated in an online education through the design of the learning environment (Loyens, Magda, \& Rikers, 2008) by providing choice and control.

While it does not seem to make a difference whether students attend synchronous virtual classes or watch the recorded virtual classes, it is important for students to attend classes. There was a significant difference in final grades between students who did not attend classes in either mode and students who did attend classes. The results of a Mann-Whitney $U$ test found a significant difference (with a large effect size, $r=$ 0.672) in the final grade between students from Group 3 (who attended 50\% or more of the synchronous virtual classes and the recorded classes) and Group 4 (who attended less than $50 \%$ of synchronous virtual classes and the recorded classes). Students from Group 3 had a median final grade of 75.25 (Distinction grade), while students of Group 4 had a median final grade of 44.25 (Fail grade). Intuitively, it makes sense that students who attend less than half of the classes would not perform academically as well as students attending more classes. It supports the assumption that class attendance is important. It is commonly assumed that class attendance facilitates learning, however, it is possible that the teacher communicates information about assessments in class that is not available elsewhere. Final grades are usually comprised of the assessment scores. Therefore, class attendance may be associated with academic success as students may have more information about assessments and may be able to self-assess their assessments more effectively (Credé et al., 2010). Wong (2013) proposed that there may be a correlation between the amount of time students spent online and the amount of time that they spent studying offline. This may include time working on assessments. 
Not all students have the same reason to attend class. Students may attend class to achieve success or to avoid failure (Eash, Seger, Windingstad, \& Lamb, 2006). Similarly, not all students have the same reason for not attending class. Students have to manage their time effective (Nieuwoudt \& Brickhill, 2017) and must make the choice to attend the class. However, students have to make "constrained choices in relation to what is available to them, the degree of risk involved and their sense of commitment to other aspects of their lives, such as employment and family" (Burke, Bennett, Bunn, Stevenson, \& Clegg, 2017, p. 35). Students enrolled in the Preparing for Success at SCU Program are typically from diverse economic, cultural, and educational backgrounds and may need to manage multiple responsibilities as carers of elderly parents or single parents (Taylor, van Eyk, \& Syme, 2018). As such, the reason for students in this study not attending class may be more complicated than simply choosing not to attend class. Online learning is more flexible, but online students may be juggling the demands of study, employment, and family obligations.

\section{Limitations and future research}

It is acknowledged that the study had several limitations. The small sample size limits the interpretations and generalisations that can be made from the results obtained. Future studies could collect data from a larger sample of online students. Online interaction and online learner participation were measured in terms of quantity rather than the quality of the interaction. Future studies can explore the quality of interactions. Focus group conversations could assist in further understanding how, when, and why students interact on the LMS. Further research is also needed to understand the reasons for attending synchronous virtual classes and/or asynchronous classes.

This study investigated how students spent their time on the LMS, but it is not known how online students spent their time offline. Future studies could investigate how online students allocate their time on a dayto-day basis to enable more effective support for students. A better understanding of online students' online and offline behaviour may lead to increased academic success, thus decreasing attrition rates. Despite the need for further studies, the results of this study may be taken into consideration for practice.

\section{Implications for practice}

Students are often attracted to online education due to the inherent flexibility. It is therefore important to ensure the flexibility that online students seek and often need to be successful in their studies. Various highquality learning activities can be incorporated to increase the quality of interactions, as students learn in different ways. The findings indicated that students who attended synchronous virtual classes did not necessarily achieve higher grades than students who watched the recorded classes. Therefore, it may not be required that students attend synchronous virtual classes, as long as there is a recording of the virtual class available for students to watch and to learn vicariously.

Educators should support and encourage students, and help students engage with the content and provide mastery experiences to increase student learning. By providing options for students and assisting students to choose the option that is best for them, academic success may be increased. Educators have to ensure that the quality of interactions on the LMS is of a high standard and that it is meaningful and facilitate learning. Educators should also make themselves available for interactions with students.

\section{Conclusions}

Learning is facilitated by student participation and interaction. The findings show there is a relationship between academic success and the number of hours students spent online. It is therefore important to provide students with multiple and varied activities (Hattie, 2012) to facilitate learning. Opportunities should be provided to engage with information in various ways (Biggs \& Tang, 2007). By using new technologies and through the effective design of the learning environment, flexibility can be increased by providing choice and control. This study aids in the understanding of the different ways students access and participate in the online learning system.

This study shows that class attendance is important. However, class attendance can consist of attending synchronous virtual classes and/or watching the recorded virtual classes. Students can interact in the synchronous virtual classes or can vicariously learn by watching other students interact in recorded classes. 
Different combinations of attending synchronous virtual classes and watching recorded classes does not necessarily result in increased academic success. However, the findings show that students who attend less than half of the classes do not perform academically as well as students attending more classes. The inclusion of varied activities are recommended to provide students with multiple opportunities to participate and interact synchronously and/or asynchronously. This may enable students to choose the mode that suit their learning style; and permit students to successfully juggle the demands of study, employment, and multiple responsibilities, to maximise their learning.

\section{References}

Abdullah, M. Y., Rahamah Abu Bakar, N., \& Mahbob, M. H. (2012). Student's participation in classroom: What motivates them to speak up? Procedia - Social and Behavioral Sciences, 51, 516522. https://doi.org/10.1016/j.sbspro.2012.08.199

Allen, M., Mabry, E., Mattrey, M., Bourhis, J., Titsworth, S., \& Burrell, N. (2004). Evaluating the effectiveness of distance learning: A comparison using meta-analysis. Journal of Communication, 54(3), 402-420. https://doi.org/10.1111/j.1460-2466.2004.tb02636.x

Anderson, T. (2003). Getting the mix right again: An updated and theoretical rationale for interaction. International Review of Research in Open and Distance Learning, 4(2). https://doi.org/10.19173/irrodl.v4i2.149

Anderson, T., \& Garrison, D. R. (1998). Learning in a networked world: New roles and responsibilities. In C. Gibson (Ed.), Distance Learners in Higher Education (pp. 97-112). Madison, WI: Atwood Publishing.

Aoki, K. (2012). Generations of distance education: Technologies, pedagogies, and organizations. Procedia - Social and Behavioral Sciences, 55(Supplement C), 1183-1187. https://doi.org/10.1016/j.sbspro.2012.09.613

Bainbridge Frymier, A., \& Houser, M. L. (2016). The role of oral participation in student engagement. Communication Education, 65(1), 83-104. https://doi.org/10.1080/03634523.2015.1066019

Bandura, A. (1986). Social foundations of thought and action: A social cognitive theory. Englewood Cliffs, NJ: Prentice Hall.

Bernard, R. M., Abrami, P. C., Borokhovski, E., Wade, C. A., Tamim, R., Surkes, M. A., \& Bethel, E. C. (2009). A meta-analysis of three types of interaction treatments in distance education. Review of Educational Research, 79(3), 1243-1289. https://doi.org/10.3102/0034654309333844

Biggs, J. B., \& Tang, C. (2007). Teaching for quality learning at university (3rd ed.). Maidenhead: McGraw Hill Education \& Open University Press.

Brookfield, S. D. (2009). Self-directed learning. In R. Maclean, \& D. Wilson (Eds.), International handbook of education for the changing world of work: Bridging academic and vocational learning. Dordrecht: Springer.

Burke, P. J., Bennett, A., Bunn, M., Stevenson, J., \& Clegg, S. (2017). It's about time: Working towards more equitable understandings of the impact of time for students in higher education. Retrieved from https://www.ncsehe.edu.au/publications/its-about-time-working-towards-more-equitableunderstandings-of-the-impact-of-time-for-students-in-higher-education/

Butner, B., Smith, A. B., \& Murray, J. (1999). Distance technology: A national study of graduate higher education programs. Online Journal of Distance Learning Administration, 2(3). Retrieved from https://www.westga.edu/ distance/butner23.html

Caspi, A., Chajut, E., Saporta, K., \& Beyth-Maron, R. (2006). The influence of personality on social participation in learning environments. Learning and Individual Differences, 16(2), 129-144. https://doi.org/10.1016/j.lindif.2005.07.003

Chandler, P., \& Sweller, J. (1991). Cognitive load theory and the format of instruction. Cognition and Instruction, 8(4), 293-332. https://doi.org/10.1207/s1532690xci0804_2

Chapin, L. A. (2018). Australian university students' access to web-based lecture recordings and the relationship with lecture attendance and academic performance. Australasian Journal of Educational Technology, 34(5), 1-12. https://doi.org/10.14742/ajet.2989

Cheng, C. K., Pare, D. E., Collimore, L., \& Joordens, S. (2011). Assessing the effectiveness of a voluntary online discussion forum on improving students' course performance. Computers \& Education, 56(1), 253-261. https://doi.org/10.1016/j.compedu.2010.07.024

Credé, M., Roch, S. G., \& Kieszczynka, U. M. (2010). Class attendance in college: A meta-analytic review of the relationship of class attendance with grades and student characteristics. Review of Educational Research, 80(2), 272-295. https://doi.org/10.3102/0034654310362998 
Dai, Y. (2019). Situating videoconferencing in a connected class toward intercultural knowledge development: A comparative reflection approach. The Internet and Higher Education, 41, 1-10. https://doi.org/10.1016/j.iheduc.2018.11.001

Davies, J., \& Graff, M. (2005). Performance in e-learning: Online participation and student grades. British Journal of Educational Technology, 36(4), 657-663. https://doi.org/10.1111/j.1467$\underline{8535.2005 .00542 . \mathrm{X}}$

Delahunty, J., Jones, P. T., \& Verenika, I. (2014). Movers and shapers: Teaching in online environments. Linguistics and Education, 28(4), 54-78. https://doi.org/10.1016/j.linged.2014.08.004

Eash, N. S., Seger, P., Windingstad, J., \& Lamb, J. (2006). Should I skip class? North American Colleges and Teachers of Agriculture, 50(3), 26-29. Retrieved from https://www.nactateachers.org/attachments/article/290/Eash_September_2006 NACTA_Journal-5.pdf

Garrison, D. R. (1997). Self-directed learning: Toward a comprehensive model. Adult Education Quarterly, 48(1), 18-33. https://doi.org/10.1177/074171369704800103

Garrison, D. R., \& Cleveland-Innes, M. (2005). Facilitating cognitive presence in online learning: Interaction is not enough. The American Journal of Distance Education, 19(3), 133-148. https://doi.org/10.1207/s15389286ajde1903_2

Gikas, J., \& Grant, M. M. (2013). Mobile computing devices in higher education: Student perspectives on learning with cellphones, smartphones \& social media. The Internet and Higher Education, 19, 18-26. https://doi.org/10.1016/j.iheduc.2013.06.002

Hattie, J. (2012). Visible learning for teachers. New York, NY: Routledge.

Hrastinski, S. (2008a). Asynchronous and synchronous e-learning. Educause Quarterly, 31(4), 51-55. Retrieved from https://er.educause.edu/ /media/files/article-downloads/eqm0848.pdf

Hrastinski, S. (2008b). What is online learner participation? A literature review. Computers \& Education, 51(4), 1755-1765. https://doi.org/10.1016/j.compedu.2008.05.005

Hrastinski, S. (2009). A theory of online learning as online participation. Computers \& Education, 52(1), 78-82. https://doi.org/10.1016/j.compedu.2008.06.009

Kahu, E., Stephens, C., Leach, L., \& Zepke, N. (2013). The engagement of mature distance students. Higher Education Research and Developments, 32(5), 791-804. https://doi.org/10.1080/07294360.2013.777036

Kebritchi, M., Lipschuetz, A., \& Santiague, L. (2017). Issues and challenges for teaching successful online courses in higher education: A literature review. Journal of Educational Technology, 46(1), 429. https://doi.org/10.1177/0047239516661713

Kinash, S., Knight, D., \& McLean, M. (2015). Does digital scholarship through online lectures affect student learning? Journal of Educational Technology \& Society, 18(2), 129-139. Retrieved from http://www.jstor.org/stable/jeductechsoci.18.2.129

Li, C., \& Irby, B. (2008). An overview of online education: Attractiveness, benefits, challenges, concerns and recommendations. College Student Journal, 42(2), 449-458. Retrieved from https://www.projectinnovation.com/college-student-journal.html

Loyens, S. M., Magda, J., \& Rikers, R. J. P. (2008). Self-directed learning in problem-based learning and its relationships with self-regulated learning. Educational Psychology Review, 20(4), 411-427. https://doi.org/10.1007/s10648-008-9082-7

McBrien, J. L., Jones, P. T., \& Cheng, R. (2009). Virtual spaces: Employing a synchronous online classroom to facilitate student engagement in online learning. International Review of Research in Open and Distance Learning, 10(3). https://doi.org/10.19173/irrodl.v10i3.605

Meyer, K. (2007, November). Student engagement in the classroom: An examination of student silence and participation. Paper presented at the annual meeting of the National Communication Association, Chicago, IL.

Meyer, K. (2008, November). Student classroom engagement: A multiple linear regression analysis of the variables predicting student silence and participation. Paper presented at the annual meeting of the National Communication Association, San Diego, CA.

National Centre for Student Equity in Higher Education. (2017). Successful outcomes for regional and remote students in Australian higher education. Retrieved from https://www.ncsehe.edu.au/ncsehefocus-successful-outcomes-for-regional-and-remote-students-in-australian-higher-education/

Nieuwoudt, J. E. (2018). Exploring online interaction and online learner participation in an online science subject through the lens of the interaction equivalence theorem. Student Success, 9(4), 53-62. https://doi.org/10.5204/ssj.v9i4.520

Nieuwoudt, J. E., \& Brickhill, M. (2017, November). Time management and attitude towards science as predictors of academic success in an enabling science subject. Paper presented the National 
Association of Enabling Educators of Australia, Gold Coast, Australia. Retrieved from https://enablingeducators.org/wp-content/uploads/2019/11/2017-Abstracts-and-Papers.pdf

Offir, B., Lev, Y., \& Bezalel, R. (2008). Surface and deep learning processes in distance education: Synchronous versus asynchronous systems. Computers \& Education, 51(3), 1172-1183. https://doi.org/10.1016/j.compedu.2007.10.009

Open Universities Australia. (2015). Online universities helping students become the first in their family to obtain higher education. Retrieved from https://www.open.edu.au/about-us/media-centre

Perera, L., \& Richardson, P. (2010). Students' use of online academic resources within a course web site and its relationship with their course performance: An exploratory study. Accounting Education, 19(6), 587-600. https://doi.org/10.1080/09639284.2010.529639

Romero, C., López, M., Luna, J., \& Ventura, S. (2013). Predicting students' final performance from participation in on-line discussion forums. Computers \& Education, 68, 458-472. https://doi.org/10.1016/j.compedu.2013.06.009

Schoech, D. (2000). Teaching over the internet: Results of one doctoral course. Research on Social Work Practice, 10(4), 467-487. https://doi.org/10.1177/104973150001000407

Skylar, A. A. (2009). A comparison of aysnchronous online text-based lectures and synchronous interactive web conferencing lectures. Issues in Teacher Education, 18(2), 69-84. Retrieved from https://files.eric.ed.gov/fulltext/EJ858506.pdf

Stone, C. (2017). Opportunity through online learning: Improving student access, participation and success in higher education. Retrieved from https://www.ncsehe.edu.au/publications/opportunityonline-learning-improving-student-access-participation-success-higher-education/

Sumuer, E. (2018). Factors related to college students' self-directed learning with technology. Australasian Journal of Educational Technology, 34(4), 29-43. https://doi.org/10.14742/ajet.3142

Sutton, L. A. (2001). The principle of vicarious interaction in computer-mediated communications. International Journal of Educational Telecommunications, 7(3), 223-242. Retrieved from https://www.learntechlib.org/primary/p/9534/

Sweller, J. (1988). Cognitive load during problem solving: Effects on learning. Cognitive Science, 12(2), 257-285. https://doi.org/10.1207/s15516709 cog1202_4

Taylor, J. A., van Eyk, T., \& Syme, S. (2018). Enabling success at university: The impact of an Australian programme to provide access to university. Journal of Further and Higher Education, 114. https://doi.org/10.1080/0309877X.2018.1504011

Wenger, E. (1998). Communities of practice: Learning, meaning, and identity. Cambridge: Cambridge University Press.

Wong, L. (2013). Student engagement with online resources and its impact on learning outcomes. Journal of Information Technology Education: Innovations in Practice, 12, 129-146. Retrieved from http://www.jite.org/documents/Vol12/JITEv12IIPp129-146Wong\%20FT116.pdf

Corresponding author: Johanna Elizabeth Nieuwoudt, johanna.nieuwoudt@scu.edu.au

Copyright: Articles published in the Australasian Journal of Educational Technology (AJET) are available under Creative Commons Attribution Non-Commercial No Derivatives Licence (CC BY-NC$\underline{\mathrm{ND}}$ 4.0). Authors retain copyright in their work and grant AJET right of first publication under CC BYNC-ND 4.0.

Please cite as: Nieuwoudt, J. E. (2020). Investigating synchronous and asynchronous class attendance as predictors of academic success in online education. Australasian Journal of Educational Technology, 36(3), 15-25. https://doi.org/10.14742/ajet.5137 